\title{
Les Jeux de la Passion dans l'Allemagne du XIV siècle, Le Rouleau de Conduite de Francfort. La Passion de Saint- Gall, traduits en français par Guy Borgnet
}

\section{G. Matteo Roccati}

\section{(2) OpenEdition}

\section{Journals}

Édition électronique

URL : http://journals.openedition.org/studifrancesi/27247

DOI : 10.4000/studifrancesi. 27247

ISSN : 2421-5856

Éditeur

Rosenberg \& Sellier

\section{Édition imprimée}

Date de publication : 31 décembre 2006

Pagination : 577

ISSN : 0039-2944

\section{Référence électronique}

G. Matteo Roccati, «Les Jeux de la Passion dans I'Allemagne du XIVe siècle, Le Rouleau de Conduite de Francfort. La Passion de Saint-Gall, traduits en français par Guy Borgnet », Studi Francesi [En ligne], 150 (L | III) | 2006, mis en ligne le 30 novembre 2015, consulté le 08 novembre 2020. URL : http:// journals.openedition.org/studifrancesi/27247 ; DOI : https://doi.org/10.4000/studifrancesi.27247

Ce document a été généré automatiquement le 8 novembre 2020.

\section{c) $(9 \ominus$}

Studi Francesi è distribuita con Licenza Creative Commons Attribuzione - Non commerciale - Non opere derivate 4.0 Internazionale. 


\title{
Les Jeux de la Passion dans l'Allemagne du XIV siècle, Le Rouleau de Conduite de Francfort. La Passion de Saint-Gall, traduits en français par Guy Borgnet
}

\author{
G. Matteo Roccati
}

\section{RÉFÉRENCE}

Les Jeux de la Passion dans l'Allemagne du XIV e siècle, Le Rouleau de Conduite de Francfort. La Passion de Saint-Gall, traduits en français par Guy BORGNET, Paris, Honoré Champion éditeur («Traductions des classiques du Moyen Age», 73), 2006, pp. 200.

1 Quoique n'appartenant pas directement à l'objet de la rassegna, ces deux textes, traduits ici pour la première fois en français, sont intéressants en tant que témoins de la forme théâtrale du mystère - forme à dimension européenne - et des modalités de sa représentation. En effet, le Rouleau (Frakfurter Dirigierrolle) est un registre de metteur en scène qui ne contient que le premier vers de chaque réplique, mais offre des didascalies très détaillées fournissant des indications scéniques précises. Il est datable du début du $\mathrm{XIV}^{\mathrm{e}}$ siècle et a servi à plusieurs représentations, comme en témoignent les ajouts et les ratures apportés sur le manuscrit.

2 La Passion (Sankt Galler Passionsspiel ou Mittelrheinisches Passionsspiel), qui est datable de la première moitié $d u$ XIV ${ }^{e}$ siècle, relève de l'aire linguistique du francique rhénan et pourrait provenir de la région située entre Mayence et Worms.

3 L'introduction présente les textes, en donne une analyse et aborde plusieurs questions s'y rapportant, notamment le rôle de saint Augustin, personnage qui intervient à l'intérieur du jeu, et l'attitude, polémique, à l'égard des juifs. Elle comporte enfin la bibliographie. Les index des personnages (établis séparément pour chaque œuvre) 
terminent le volume. La traduction a été réalisée sur les éditions R. Froning (1891-1892) et R. Schützeichel (1978). 